\title{
History of the Russian Zapovedniks 1985-1995
}

By F. Shtilmark. (Translated from Russian by G. H. Harper). 2003. Russian Nature Press (www.rusnatpress.org.uk). 307 pages, $£ 30.95$

This book makes a major contribution to the environmental history of Russia, its influence zone and also to the global nature heritage. The Zapovedniks Russia's protected nature reserve system - have withstood the test of time, although it has been distorted by social and political factors. Due to the great English translation by G. H. Harper, the Russian Nature Press offers us new views on conservation, as well as solutions to the current problems with protected areas world-wide. The original text is written by one of the leading Russian environmental writers and fascinatingly energetic activists providing for superb inside knowledge unknown to the western world. His visions are guided by principles such as "we have a duty to make our zapovedniks and national parks the pride of Russia...".

In this great book the reader will learn about Russia's nature, and foremost, about how to protect it during such fascinating and complex times like Tsarism, the rules of Lenin and Stalin, and Gorbachovs' glasnost and perestroika (the book manuscript was finished 1996). Throughout the history of the Zapovedniks (in short called Zap's) the role of the Academy of Science proves very significant. The composition and attitude of its board members towards protection vs. exploitation play a crucial role for Zap-Management (and species survival).

Most readers will likely be surprised to learn that the Russian Zapovednik system actually acted as a model for setting up the global network of biosphere reserves. But to this very day there exists a fundamental confusion in the western world regarding the terminology and meaning of Russian protected nature reserves. As described over the 307 pages, westernstyle National Parks represent only one component in the complex Russian system of Zapodniks, Zapovednosts, Zapovednayes and Zakazniks. A critical view of the author refers to National Parks simply as pseudo-zapovedniks because "An absolute Zapovednik is an area of land or water that together with all products of nature on and in it (plants, animals, soils, rocks, minerals) is preserved in perpetuity and in a state of inviolability".

Many Zapovednys were originally used for the Tsars or as a prince's hunting estate, e.g., the famous Kuban Hunting Reserve. So originally, these systems go back to land grants from the aristocrats. But the author takes great care in explaining that Qualified Zapovedniks have a weaker definition in their protection status, allowing for human use. A Zapovednost implies the complete withdrawal of an area of land from any economic use. The biological theory of Zapovednosts rests on the idea of an ecological equilibrium, and the capac- ity of organisms to regulate themselves in the absence of direct human influence. Zapovedaniye means a withdrawal of a certain area of nature from the sphere of ordinary economic activity for the attainment of particular non-traditional economic, social and ecological purposes. It represents samples of "virgin nature selected for comparison with exploited land". Zapovedny Management relates to a method of managing protected territories and water bodies. Further, one can find Zapovednik Museums, as well as Game Zapovedniks and even Spa-Zapovedniks. Only the Zakazniks are areas set aside for hunting. Finally, the Etalons are protected areas, model examples, representative for a specific ecosystem type and completely free from human influence.

Several black/white maps, portraits, tables and diagrams are presented, and including with some painted Russian scenery, turn this publication into a precious book to own.

The book makes a nice case that fur-bearing animals were considered as Russia's "Soft Gold"; they were one of the chief resources for foreign income. This wealth created the influential Moscow Fur Institute. Besides the earlier over-exploitation of Russian beaver resources, the $20^{\text {th }}$ century showed also a sharp decline of sable, and a subsequent nation-wide harvest moratorium was not really effective. Therefore, sable reserves were requested, and a Sable Zakaznik was set up by local people in Kamchatka as early as 1882 . These Game Zapovedniks were called Superior Zapovedniks in which hunting was not allowed, and breeding programs were initiated.

As elsewhere in the world, the tensions around protected areas were intense. Borders of Zapovedniks were often not followed or defined even. Poaching was common in taiga Zapovedniks or where "old believers", Chinese bandits, and fur-traders lived. In Crimea and elsewhere, the designated Zap-guards and zoo-staff were tortured or even executed.

Besides the many day to day struggles in Zapovedniks, Lenin's revolution then had a massive restructuring in place for them, resulting in the "Socialisation of the Land". It converted the entire country in a gigantic "national park"; ownership rights were removed with one stroke. Lenin was a hunter himself and had a great interest in nature affairs. That proved to be fortunate for Russia's nature, as well as for some aspects of the global environment. From that point on, the Russian Soviet Federal Socialist Republic (RSFSR, founded $25^{\text {th }}$ October 1917) played a crucial role in the protected areas, and started its well known enthusiasm for regulations.

Some Russian Zapovednik administrators used the guiding principle "Nature is not a cathedral, but a workshop". And typical Zapovednik tasks dealt with the introduction ("Acclimatisation") and control of animal populations. Culling was part of most Zapovedniks, 
and the culled game meat was contributed to the social food-supply or else was sold to Zapovednik staff. The elimination of crows, and cormorants as fish-eating birds took place Russia-wide. Bears, marten, gulls, skuas, crows, hawks and eagles got killed en masse. Extensive campaigns against wolves by poison and air were carried out for almost a century shaping the Russian culture against predators to this very day.

The text reads like a crime story. As felt in many other places in the world, the Stalinist revolution further led to more and major changes. Namely, a shift from nature protection to exploitation in the interest of the socialist construction. Protecting nature for the sake of nature was not en vogue anymore. Further, "Bourgeois" professors who comprised a large proportion of the conservation's cadre in the Soviet state in the 1930s were eliminated, and many members of the Academy of Science got arrested. From then on, Zapovedniks were explored for minerals, coal and oil deposits, timber resources and fur bearing resources, culminating in slogans like "We must take the Urals apart". The fetish of inviolability as a bourgeois theory got sacrified. Protection was now defined as exploitation. Under comrade Stalin, Zapovedniks turned into multi-purpose economic enterprises. It led to the view that planned exploitation of Natural Resources would be the main pre-condition of Nature Protection.

From the 1960s onwards the Zapovednik system experienced a modernization. A. G. Bannikov and G. P. Dementev started to participate in the IUCN. RussianJapanese international migratory bird conventions got signed. In 1970-71 the UNESCO biosphere reserves "Man and Biosphere" were established. In 1972 a U.S.Russian agreement on protecting the natural environment got accomplished, and the USSR Red Data book came into place.

As early as 1975 multidisciplinary monitoring was demanded in Russia, a theme that is very relevant for today even, and not achieved by most countries yet. When cheap fuel got provided for that purpose to the Zapovedniks by the state, they got quickly swamped with motorboats, snow tractors and motorcycles. Helicopters can be added to the list as well since flying was very common by then. The author explains that caterpillars tracked and wheeled cross-country, and vehi-

\section{A Field Guide to the Identification of Pebbles}

By E. Van der Flier-Keller. 2007. Harbour Publishing, Box 219 Madeira Park, British Columbia V0N 2H0 Canada. 9 inch by 8 inch pamphlet, $\$ 7.95$

Professor Van der Flier-Keller has produced a neat pebble guide for children. She has condensed fundamental pebble geology into a single page. Then she portrays 34 types of rock as they appear when they are transformed into pebbles. She adds in a few manmade objects that also appear on beaches, such as glass. The pamphlet is a single long sheet of plasticized paper cles ploughed up the tundra on Vrangel and Taymyr.

In the 1990s, the U.S. American Soros and MacArthur Foundations with their foreign funds gained considerable influence over Russia's nature; WWF, Evraziya, the Japanese Society for the Protection of Birds, the Global Ecological Facility, and the International Bank for Reconstruction \& Development were other international players accounting for as much as one quarter of Western money on the expenditure for protecting Russia's biodiversity. This foreign influence made many Russian politicians extremely uneasy.

However, despite all of these gigantic efforts, and similar to the case in North America, nothing remains of the many original habitats such as the steppe. "We now need to introduce the specially-protected areas system almost forcibly to counterbalance irrational natural-resource-use, and to prevent deterioration of landscapes and valuable sites".

It becomes clear from the text that Russia and its Zapovedniks etc. are not set up for the information society at all, and thus Russian high quality online (raw) data are hard to come by still. Much crucial biodiversity information is published though in hardcopy and journals, or exists in filing cabinets, private ownerships and cabinets, and as expert knowledge. Otherwise, check the Russian Conservation News found online www.russianconservation.org.

One cannot find a better and centralized overview of Russian conservation history issues than this book; its detailed Appendices are further assets consisting of current and former Zapovednik lists, a Kyrillic reference list and in-depth annotations for each chapter. I find that this book is a little too friendly on the widespread view in Russia that traditional Zapovednik management caters primarily to the Russian race but leaves natives and other ethnical groups out. Marine protected areas were apparently not really part of Russia's nature protection system either.

However, "Come back in hundred years, then let's talk" (And in the meantime, I highly suggest buying and reading this important book).

Falk Huettmann

Institute of Arctic Biology, Biology \& Wildlife Department, University of Alaska-Fairbanks, Alaska 99775 USA

with clear, "life" size photographs of pebbles. It is easy to use and is ideal for children as it does not get overcomplicated and therefore overwhelming. For example, it only shows two forms of granite - pink and white. This is quite sufficient for an 8-year old to absorb. While the author has reduced the text to a simple explanation she does use the correct technical terms throughout. Younger children may need help with some of the terms (plutonic) or concepts (glacial deposits), but then this is what parents are for. The pamphlet folds 